\title{
Variability in $A P O E$ genotype status in human-derived cell lines: a cause for concern in cell culture studies?
}

\author{
Sebastian Schaffer • Vanessa Y. M. Lam • \\ Insa M. A. Ernst • Patricia Huebbe • \\ Gerald Rimbach · Barry Halliwell
}

Received: 4 September 2013/Accepted: 4 November 2013/Published online: 3 December 2013

(c) Springer-Verlag Berlin Heidelberg 2013

\begin{abstract}
Although cell culture studies have provided landmark discoveries in the basic and applied life sciences, it is often under-appreciated that cells grown in culture are prone to generating artifacts. Here, we introduce the genotype status (exemplified by apolipoprotein E) of human-derived cells as a further important parameter that requires attention in cell culture experiments. Epidemiological and clinical studies indicate that variations from the main apolipoprotein $E 3 / E 3$ genotype might alter the risk of developing chronic diseases, especially neurodegeneration, cardiovascular disease, and cancer. Whereas the apolipoprotein $\mathrm{E}$ allele distribution in human populations is well characterized, the apolipoprotein $\mathrm{E}$ genotype of humanderived cell lines is only rarely considered in interpreting cell culture data. However, we find that primary and immortalized human cell lines show substantial variation in their apolipoprotein E genotype status. We argue that the apolipoprotein E genotype status and corresponding gene expression level of human-derived cell lines should be considered to better avoid (or at least account for) inconsistencies in cell culture studies when different cell lines of
\end{abstract}

S. Schaffer · V. Y. M. Lam · B. Halliwell

Department of Biochemistry, Centre for Life Sciences, Yong

Loo Lin School of Medicine, National University of Singapore,

Singapore 117597, Singapore

I. M. A. Ernst - P. Huebbe - G. Rimbach

Institute of Human Nutrition and Food Science,

University of Kiel, 24118 Kiel, Germany

B. Halliwell ( $\square)$

National University of Singapore, University Hall, Lee Kong

Chian Wing, UHL \#05-02G, 21 Lower Kent Ridge Road,

Singapore 119077, Singapore

e-mail: bchbh@nus.edu.sg the same tissue or organ are used and before extrapolating cell culture data to human physiology in health and disease.

Keywords APOE - Cell culture artifacts - Humanderived cell lines · Genotyping · Cardiovascular disease $\cdot$ Neurodegeneration

Cell lines derived from humans or other animals are commonly used tools which dominate many research fields in the basic and applied life sciences. Some of the main reasons for conducting cell culture experiments, rather than in vivo studies, are their comparatively low input requirement in terms of time, labor, and financial resources (Freshney 2005). Indeed, cell culture studies have provided landmark discoveries, such as the identification of the tumor suppressor protein p53 and the description of telomeres as important regulators of the cell cycle and cell senescence machinery (Olovnikov 1973; Lane and Crawford 1979; Shampay et al. 1984). At the same time, however, it is important to remember that cells grown in culture have not only been removed from their natural environment but are often prone to generating cell culture artifacts. We know, for example, that the oxygen concentrations in most mammalian organs and tissues range from 1 to $6 \%$ (with up to $14 \%$ in arterial blood) to ensure physiological tissue function but at the same time to minimize the production of potentially detrimental reactive oxygen and nitrogen species (Roy et al. 2003; Sullivan et al. 2006; Shay and Wright 2007; Halliwell and Gutteridge 2007; Oze et al. 2012). Yet, most cell culture experiments are conducted in an atmosphere unnaturally rich in oxygen due to the cells' exposure to normal air which contains $21 \%$ oxygen (Halliwell 2003). There is good experimental evidence that such a high oxygen concentration often exerts 
detrimental effects on cell metabolism and subsequently cell growth and survival (Alaluf et al. 2000; Busuttil et al. 2003; Estrada et al. 2012; Long and Halliwell 2012). Other important contributors to artifactual data are the use of misidentified cell lines (Nardone 2008; American Type Culture Collection Standards Development Organization Workgroup ASN-0002 2010) and the instability of test compounds added into cell culture media. Whereas the reaction of autoxidizable test compounds (e.g., ascorbate, epigallocatechin-3-gallate, quercetin) with components of cell culture media can produce hydrogen peroxide (Long et al. 2000; Halliwell 2003; Long and Halliwell 2012), some test compounds (e.g., curcumin and resveratrol) rapidly decompose into agents often with unknown biological activities (Long et al. 2010). Genomic instability of cells in long-term culture is another area of concern (Gazdar et al. 2010; Skrobot et al. 2007). Depending on the experimental conditions, an approximately 30 -fold variation in the spontaneous mutation rate has been determined for the mouse lymphoma cell line, GRSL13 (Boesen et al. 1994), for example. Such cell culture-induced genetic alterations might not only affect immortalized cell lines, but also, for instance, embryonic stem cells (Skrobot et al. 2007; Wu et al. 2011; Amps et al. 2011).

Here, we would like to introduce the genotype status of human-derived cells as another important parameter that requires attention in cell culture experiments. The genetic profile of cells is mechanistically important as it largely determines their phenotype and thus their response pattern to environmental changes (Desiere 2004; Ferguson 2008; Sharp et al. 1997) both in vivo and, as we will argue, also in vitro. In this regard, the apolipoprotein $\mathrm{E}(A P O E)$ genotype is probably one of the best-known genetic factors with respect to onset and progression of several common chronic diseases (Davignon et al. 1988; Mrkonjic et al. 2009; Arold et al. 2012). From two SNPs, three alleles arise (APOE2, APOE3 and APOE4) which encode the main protein isoforms apoE2, apoE3, and apoE4 (Weisgraber et al. 1981). Various tissues express APOE, most notably liver (about $2 / 3$ of total apoE synthesis), immune cells (macrophages, neutrophils), brain (especially astrocytes), spleen and kidney (Zhang et al. 2011). In addition, APOE expression has been detected in heart, testis, prostate, pancreas, and several other organs (Zannis et al. 1985; Law et al. 1997). Functionally, the apoE protein acts as a key regulator of cholesterol and lipid metabolism (Fazio et al. 2000).

Several studies describe an increased risk for cardiovascular disease (CVD) in APOE4 carriers (Davignon et al. 1988), probably originating from elevated levels of LDL cholesterol, although the exact mechanisms underlying the APOE4-CVD-risk associations are likely to be more complex (Minihane et al. 2007). Similarly, the APOE genotype exerts strong effects on the pathological processes leading to neurodegenerative diseases (Maezawa et al. 2006; Kornecook et al. 2010; Arold et al. 2012). Indeed, the prevalence of Alzheimer's disease dramatically increases with the number of APOE4 alleles (Corder et al. 1993), while lifespan is shortened in APOE4 carriers (Smith 2002; Christensen et al. 2006). Furthermore, recent evidence indicates that possession of the APOE4 genotype may not only significantly affect the levels of biomarkers of oxidative stress and inflammation in animal models and humans (Dietrich et al. 2005; Vitek et al. 2009; Graeser et al. 2012), but may also regulate their vitamin D levels as well as vitamin E uptake (Huebbe et al. 2009, 2011). Consequently, variations in the APOE genotype are frequently considered in the analysis of clinical data (Corder et al. 1993; Minihane et al. 2007). In contrast, the APOE genotype status has rarely been taken into account in the plethora of published studies conducted in human-derived cell lines (Dupont-Wallois et al. 1997; Riddell et al. 2008; Jeannesson et al. 2009). We suggest that it is time to rethink.

First, the impact that different $A P O E$ genotypes can exert on the metabolism of cells in culture and their phenotypic behavior is well established. In agreement with in vivo data, cells of animal origin transfected with human $A P O E$ and those obtained from human $A P O E$-targeted replacement mice show distinct $A P O E$ genotype-dependent differences in their cellular responses. Several studies suggest significantly increased levels of oxidative stress and inflammatory biomarkers in apoE4-synthesizing cells (Colton et al. 2002; Jofre-Monseny et al. 2007). In addition, considerable evidence demonstrates that apoE4 can, at least under certain circumstances, induce mitochondrial dysfunction in cells (Chen et al. 2011). Possible explanations for these findings are apoE isoform-dependent differences in apoE degradation and in the expression level of disease-modifying proteins, such as $\mathrm{NF \kappa B}$, Nrf2, and metallothionein (Ophir et al. 2005; Elliott et al. 2011; Graeser et al. 2011, 2012). Furthermore, apoE isoform- and dose-dependent effects, for example, on hydrogen peroxide scavenging and metal chelation, have been reported (Miyata and Smith 1996). The exact pathological mechanisms of apoE4 at the cellular level, however, remain to be elucidated.

Second, a screen conducted in our two laboratories of all locally available human-derived cell lines reveals substantial variations in their APOE genotype status (Table 1). Among those cell lines which were hetero- or homozygous for the APOE2 or APOE4 allele (and thus diverge from the most common APOE3/E3 genotype) are popular cancer and immortalized cell lines, such as HaCat (APOE2/E4), HeLa (APOE3/E4), PC-3 (APOE2/E2), and U937 (APOE4/ $E 4)$ as well as several primary cell lines obtained from 
Table 1 APOE genotype status of human-derived cell lines

\begin{tabular}{|c|c|c|c|c|c|c|c|c|}
\hline \multirow[t]{2}{*}{ No. } & \multirow{2}{*}{$\begin{array}{l}\text { Tissue } \\
\text { of origin }\end{array}$} & \multirow[t]{2}{*}{ Cell line } & \multirow[t]{2}{*}{ Cell line description } & \multirow{2}{*}{$\begin{array}{l}\text { Primary cell } \\
\text { line (yes/no) }\end{array}$} & \multicolumn{3}{|c|}{ Donor details ${ }^{\mathrm{a}}$} & \multirow{2}{*}{$\begin{array}{l}A P O E \\
\text { genotype }\end{array}$} \\
\hline & & & & & $\begin{array}{l}\text { Age } \\
\text { (years) }\end{array}$ & Gender & Ethnicity & \\
\hline 1 & Aorta & VSMC & Vascular smooth muscle & Yes & 11 Months & $\mathrm{F}$ & Caucasian & $\mathrm{E} 3 / \mathrm{E} 4$ \\
\hline 2 & Blood & HL 60 & Human acute promyelocytic leukemia & No & 36 & $\mathrm{~F}$ & Caucasian & E3/E3 \\
\hline 3 & & $\begin{array}{l}\text { Jurkat Clone } \\
\text { E6-1 }\end{array}$ & Human acute $\mathrm{T}$ lymphocytes leukemia & No & 14 & M & - & E3/E3 \\
\hline 4 & & THP-1 & Human acute monocytic leukemia & No & 1 & M & - & E3/E3 \\
\hline 5 & & U937 & Human histiocytic lymphoma & No & 37 & M & Caucasian & $\mathrm{E} 4 / \mathrm{E} 4$ \\
\hline 6 & Bone & $\begin{array}{l}\text { HTB } \\
\quad 85 / \text { Saos-2 }\end{array}$ & Human bone osteosarcoma & No & 11 & $\mathrm{~F}$ & Caucasian & E2/E3 \\
\hline 7 & & $\begin{array}{l}\text { HTB } \\
\text { 94/SW1353 }\end{array}$ & Human bone chondrosarcoma & No & 72 & $\mathrm{~F}$ & Caucasian & E2/E3 \\
\hline 8 & & $\mathrm{HAC}$ & Human articular chondrocytes & Yes & - & - & - & E3/E3 \\
\hline 9 & Brain & CCF-STTG1 & Human astrocytoma & No & 68 & $\mathrm{~F}$ & Caucasian & $\mathrm{E} 3 / \mathrm{E} 4$ \\
\hline 10 & & Kelly cells & Human neuroblastoma & No & - & - & - & $\mathrm{E} 3 / \mathrm{E} 4$ \\
\hline 11 & & SH-SY5Y & Human neuroblastoma & No & 4 & $\mathrm{~F}$ & - & E3/E3 \\
\hline 12 & & U87 & Human glioblastoma/astrocytoma & No & 44 & - & Caucasian & E3/E3 \\
\hline 13 & & $\mathrm{U} 118$ & Human glioblastoma/astrocytoma & No & 50 & M & Caucasian & $\mathrm{E} 2 / \mathrm{E} 4$ \\
\hline 14 & Breast & MCF-7 & Human breast adenocarcinoma & No & 69 & $\mathrm{~F}$ & Caucasian & E3/E3 \\
\hline 15 & Cervix & $\mathrm{HeLa}$ & Human cervix adenocarcinoma & No & 31 & $\mathrm{~F}$ & African & $\mathrm{E} 3 / \mathrm{E} 4$ \\
\hline 16 & Colon & $\mathrm{CaCo}-2$ & Human colorectal adenocarcinoma & No & 72 & M & Caucasian & E3/E3 \\
\hline 17 & & HCT 116 & Human colorectal carcinoma & No & Adult & M & - & E3/E3 \\
\hline 18 & & HT 29 & Human colorectal adenocarcinoma & No & 44 & $\mathrm{~F}$ & Caucasian & E3/E3 \\
\hline 19 & & RKO & Human colon carcinoma & No & - & - & - & $\mathrm{E} 3 / \mathrm{E} 4$ \\
\hline 20 & & CCD33Co & Human normal colon fibroblasts & Yes & 7 & M & Caucasian & $\mathrm{E} 2 / \mathrm{E} 4$ \\
\hline 21 & $\begin{array}{c}\text { Fusion } \\
\text { cell } \\
\text { line }\end{array}$ & EA.hy926 & $\begin{array}{l}\text { Somatic cell hybrid of primary HUVEC and } \\
\text { thio-guanine resistant clone A549 }\end{array}$ & No & - & - & - & E3/E3 \\
\hline 22 & Kidney & HEK 293 & Human embryonic kidney & No & Fetus & - & - & E3/E3 \\
\hline 23 & & $\mathrm{HK}-2$ & $\begin{array}{l}\text { Immortalized human normal kidney } \\
\text { proximal tubule epithelial cells }\end{array}$ & No & Adult & M & - & E3/E3 \\
\hline 24 & & RPTEC & $\begin{array}{l}\text { Human normal renal proximal tubular } \\
\text { epithelial cells }\end{array}$ & Yes & - & - & - & E2/E3 \\
\hline 25 & Liver & HepG2 & Human hepatocellular carcinoma & No & 15 & M & Caucasian & E3/E3 \\
\hline 26 & & $\mathrm{HuH}-7$ & Human hepatocellular carcinoma & No & 57 & M & Japanese & E3/E3 \\
\hline 27 & & Kyn 2 & $\begin{array}{l}\text { Human pleomorphic hepatocellular } \\
\text { carcinoma }\end{array}$ & No & 52 & M & Japanese & E3/E3 \\
\hline 28 & & $\mathrm{HFH}$ & Human fetal hepatocytes & Yes & - & - & - & $\mathrm{E} 3 / \mathrm{E} 4$ \\
\hline 29 & Lung & A549 & Human alveolar basal carcinoma & No & 58 & M & Caucasian & E3/E3 \\
\hline 30 & & 16HBE140 & Human bronchial epithelial cells & Yes & - & - & - & E3/E3 \\
\hline 31 & & IMR90 & Human normal lung fibroblasts & Yes & 16 Weeks & $\mathrm{F}$ & Caucasian & E3/E3 \\
\hline 32 & Prostate & PC-3 & Human prostate carcinoma & No & 62 & M & Caucasian & $\mathrm{E} 2 / \mathrm{E} 2$ \\
\hline 33 & & DU145 & Human prostate carcinoma (from brain) & No & 69 & M & Caucasian & E3/E3 \\
\hline 34 & & $\mathrm{LNCaP}$ & $\begin{array}{l}\text { Human prostate carcinoma (from lymph } \\
\text { node) }\end{array}$ & No & 50 & M & Caucasian & E3/E3 \\
\hline
\end{tabular}


Table 1 continued

\begin{tabular}{|c|c|c|c|c|c|c|c|c|}
\hline \multirow[t]{2}{*}{ No. } & \multirow{2}{*}{$\begin{array}{l}\text { Tissue } \\
\text { of origin }\end{array}$} & \multirow[t]{2}{*}{ Cell line } & \multirow[t]{2}{*}{ Cell line description } & \multirow{2}{*}{$\begin{array}{l}\text { Primary cell } \\
\text { line (yes/no) }\end{array}$} & \multicolumn{3}{|c|}{ Donor details $^{\mathrm{a}}$} & \multirow{2}{*}{$\begin{array}{l}A P O E \\
\text { genotype }\end{array}$} \\
\hline & & & & & $\begin{array}{l}\text { Age } \\
\text { (years) }\end{array}$ & Gender & Ethnicity & \\
\hline 35 & \multirow[t]{8}{*}{ Skin } & HaCat & Immortalized human normal keratinocytes & No & 62 & M & Caucasian & $\mathrm{E} 2 / \mathrm{E} 4$ \\
\hline 36 & & NEB-1 & $\begin{array}{l}\text { Immortalized human normal Epidemolysis- } \\
\text { Bullosa cells }\end{array}$ & No & - & - & - & E3/E3 \\
\hline 37 & & CRL 2115 & Human normal skin fibroblasts & Yes & 27 & M & Caucasian & E3/E3 \\
\hline 38 & & GM16678 & Human RCP-3 skin fibroblasts & Yes & 4 Months & $\mathrm{F}$ & $\begin{array}{r}\text { Caucasian/ } \\
\text { Lebanese }\end{array}$ & E3/E3 \\
\hline 39 & & HDFn & Human dermal fibroblasts & Yes & Neonatal & - & - & E3/E4 \\
\hline 40 & & KF116 & Human keloid fibroblasts & Yes & - & - & - & E3/E3 \\
\hline 41 & & KF112 & Human dermal fibroblasts (from breast) & Yes & 35 & $\mathrm{~F}$ & Chinese & $\mathrm{E} 2 / \mathrm{E} 3$ \\
\hline 42 & & PHK & Human keratinocytes & Yes & - & - & - & E3/E3 \\
\hline
\end{tabular}

The APOE genotype was determined either by RFLP analysis (Singapore) or by TaqMan ${ }^{\circledR}$ method (Germany). A subset of data was taken from (Dupont-Wallois et al. 1997; Riddell et al. 2008; Jeannesson et al. 2009)

a Donor details were obtained from various cell line repositories [Japanese Collection of Research Bioresources (http://www.cellbank.nibio.go. jp), ATCC (http://www.atcc.org), NIGMS Human Genetics Cell Repository, Coriell Institute (http://ccr.coriell.org/Sections/Collections/NIGMS/ ?SsId=8), Cell Lines Service (http://www.cell-lines-service.de/content/index_eng.html); all accessed electronically on 28/11/2011]; details for cell lines KF116 and KF112 were obtained from the Wound Healing and Stem Cell Research Group (NUS)

human donors (Table 1). Despite our comparatively small sample size, examples of cell lines diverging from the main $A P O E 3 / E 3$ genotype were found for all human organs and tissues of origin (e.g., blood, bone, brain, cervix, colon, heart, kidney, liver, prostate, and skin) included here, with the exception of human lung and breast tissue-derived cells (as well as the fusion cell line EA.hy926; kindly provided by Prof. C. J. Edgell, University of North Carolina at Chapel Hill). Of note, from the APOE allele distributions depicted in Fig. 1a, which was not significantly different between human-derived cell lines and published population data, it follows that the probability of selecting a humanderived cell line carrying the most commonly found APOE3/E3 genotype is about 50-60\%. Conversely, scientists who randomly select a cell line originating from a human donor have an approximately 40-50\% chance of conducting experiments with cells whose genotype deviates from the main $A P O E 3 / E 3$ genotype (Fig. 1b).

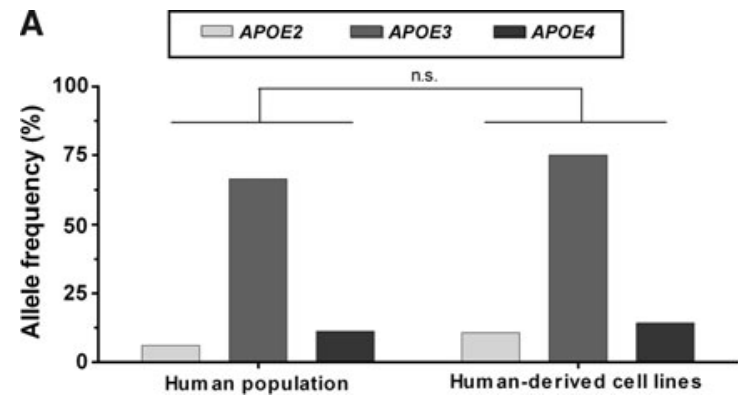

Fig. 1 APOE comparison between human world population (Singh et al. 2006) and human-derived cell lines. a Allele frequency for $A P O E 2, A P O E 3$, and APOE4. Selected data sets were analyzed by $\chi^{2}$
Third, the actual impact that a particular polymorphism exerts on cell physiology and disease susceptibility depends on the level of gene expression (Jeannesson et al. 2009). As mentioned before, various tissues express $A P O E$, although at different levels (Zannis et al. 1985; Law et al. 1997; Zhang et al. 2011). However, one must be careful of automatically assuming that cells obtained from human $A P O E$-expressing tissue show similar levels of $A P O E$ gene expression in vitro. As an immune cell, the human macrophage-like U937 cell line (APOE4/E4) is expected to express $A P O E$. Previous studies, however, failed to detect $A P O E$ mRNA in this cell line cultured both under standard conditions or the presence of $A P O E$ expression inducers such as dexamethasone, thus limiting their suitability for studying CVD and other disease mechanisms (Zannis et al. 1985). Similarly, no endogenous $A P O E$ gene expression has been found in HeLa cells (APOE3/E4) (Smith et al. 1988). In a direct comparison of three human prostate

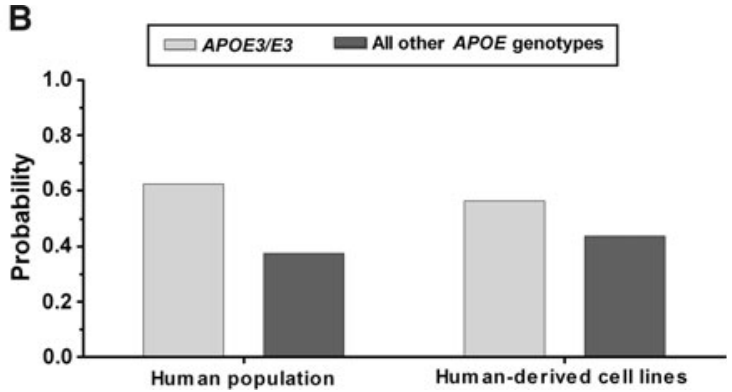

test (n.s., non-significant). b Probability to select an $A P O E 3 / E 3$ compared to any of the other $A P O E$ genotypes (i.e., APOE2/E2, APOE2/E3, APOE3/E4, APOE4/E4, APOE2/E4) 
carcinoma cell lines, $A P O E$ was highly expressed in PC-3 cells (APOE2/E2), detectable in DU145 cells (APOE3/E3) but absent in LNCaP cells (APOE3/E3) (Venanzoni et al. 2003), thus again highlighting the importance of determining both $A P O E$ genotype and expression level for minimizing biased data interpretation. Interestingly, PC-3 cells were highly tumorigenic, DU-145 cells were moderately tumorigenic, and $\mathrm{LNCaP}$ cells were only weakly tumorigenic (Venanzoni et al. 2003). It is tempting to speculate that the tumorigenic potential of the three human prostate carcinoma cell lines was influenced not only by the actual apoE expression level but also by the differences in the $A P O E$ genotype status.

Taken together, we think that the data and arguments summarized above warrant a more widespread consideration of the $A P O E$ genotype status by research groups working with human-derived cell lines. In addition to immortalized cell lines, this approach is particularly important when working with primary cells as their $A P O E$ genotype might vary with each new donor. Of course, as the cause of most diseases is not monogenetic, a cell's response to experimental stimuli depends not only on the presence of a particular APOE genotype, but on the presence and interplay of various risk genes in a given environment (Jeannesson et al. 2009). Considering that many chronic disease processes are driven, at least partly, by inflammation and oxidative stress, we suggest that SNPs of genes associated with both phenomena are probably also worth monitoring. Screening human-derived cell lines for the presence of polymorphisms in the tumor necrosis factor alpha (Elahi et al. 2009; Qidwai and Khan 2011) and paraoxonase-1/-2 genes (Shih and Lusis 2009; Schrader and Rimbach 2011) might be particularly interesting in this context. Ultimately, it might be necessary to genotype a particular human-derived cell line for several, and sometimes even all, gene variants that are known to be important in cell metabolism. As discussed for U937 and the set of human prostate carcinoma cells, the obtained genotype data should be ideally supplemented with information regarding the actual gene expression (i.e., effective protein level). Obviously, the final course of action should always be context-driven.

From a practical point of view, genotyping can be accomplished comparatively easily by RFLP or TaqMan ${ }^{\circledR}$ probe analysis (Table 1) or by one of the other methods published in the recent literature (Hixson and Vernier 1990; Calero et al. 2009; Rihn et al. 2009). Similarly to cell line authentication data, information regarding the genotype status of human-derived cell lines should be made easily available, perhaps in the form of an online database. We believe that the genotype status and the corresponding gene expression level of human-derived cell lines could help the scientific community to better avoid (or at least account for) inconsistencies in cell culture studies when different cell lines of the same tissue or organ are used and before extrapolating cell culture data to human physiology in health and disease.

Acknowledgments BH, SS, and VL are most grateful for financial support provided by the Biomedical Research Council of Singapore (BMRC Grant 09/1/21/19/598).

Conflict of interest None.

\section{References}

Alaluf S, Muir-Howie H, Hu HL et al (2000) Atmospheric oxygen accelerates the induction of a post-mitotic phenotype in human dermal fibroblasts: the key protective role of glutathione. Differentiation 66:147-155

American Type Culture Collection Standards Development Organization Workgroup ASN-0002 (2010) Cell line misidentification: the beginning of the end. Nat Rev Cancer 10:441-448

Amps K, Andrews PW, Anyfantis G et al (2011) Screening ethnically diverse human embryonic stem cells identifies a chromosome 20 minimal amplicon conferring growth advantage. Nat Biotechnol 29:1132-1144

Arold S, Sullivan P, Bilousova T et al (2012) Apolipoprotein E level and cholesterol are associated with reduced synaptic amyloid beta in Alzheimer's disease and apoE TR mouse cortex. Acta Neuropathol 123:39-52

Boesen JJ, Niericker MJ, Dieteren N et al (1994) How variable is a spontaneous mutation rate in cultured mammalian cells? Mutat Res 307:121-129

Busuttil RA, Rubio M, Dolle ME et al (2003) Oxygen accelerates the accumulation of mutations during the senescence and immortalization of murine cells in culture. Aging Cell 2: 287-294

Calero O, Hortiguela R, Bullido MJ et al (2009) Apolipoprotein E genotyping method by real time PCR, a fast and cost-effective alternative to the TaqMan and FRET assays. J Neurosci Method 183:238-240

Chen HK, Ji ZS, Dodson SE et al (2011) Apolipoprotein E4 domain interaction mediates detrimental effects on mitochondria and is a potential therapeutic target for Alzheimer disease. J Biol Chem 286:5215-5221

Christensen K, Johnson TE, Vaupel JW (2006) The quest for genetic determinants of human longevity: challenges and insights. Nat Rev Genet 7:436-448

Colton CA, Brown CM, Cook D et al (2002) APOE and the regulation of microglial nitric oxide production: a link between genetic risk and oxidative stress. Neurobiol Aging 23:777-785

Corder EH, Saunders AM, Strittmatter WJ et al (1993) Gene dose of apolipoprotein E type 4 allele and the risk of Alzheimer's disease in late onset families. Science 261:921-923

Davignon J, Gregg RE, Sing CF (1988) Apolipoprotein E polymorphism and atherosclerosis. Arteriosclerosis 8:1-21

Desiere F (2004) Towards a systems biology understanding of human health: interplay between genotype, environment and nutrition. Biotechnol Annu Rev 10:51-84

Dietrich M, Hu Y, Block $\mathrm{G}$ et al (2005) Associations between apolipoprotein E genotype and circulating F2-isoprostane levels in humans. Lipids 40:329-334

Dupont-Wallois L, Soulie C, Sergeant N et al (1997) ApoE synthesis in human neuroblastoma cells. Neurobiol Dis 4:356-364 
Elahi MM, Asotra K, Matata BM et al (2009) Tumor necrosis factor alpha -308 gene locus promoter polymorphism: an analysis of association with health and disease. Biochim Biophys Acta 1792:163-172

Elliott DA, Tsoi K, Holinkova S et al (2011) Isoform-specific proteolysis of apolipoprotein-E in the brain. Neurobiol Aging 32:257-271

Estrada JC, Albo C, Benguria A et al (2012) Culture of human mesenchymal stem cells at low oxygen tension improves growth and genetic stability by activating glycolysis. Cell Death Differ 19:743-755

Fazio S, Linton MF, Swift LL (2000) The cell biology and physiologic relevance of ApoE recycling. Trends Cardiovasc Med 10:23-30

Ferguson LR (2008) Dissecting the nutrigenomics, diabetes, and gastrointestinal disease interface: from risk assessment to health intervention. OMICS 12:237-244

Freshney RI (2005) Culture of animal cells: a manual of basic technique. Wiley, New York

Gazdar AF, Gao B, Minna JD (2010) Lung cancer cell lines: useless artifacts or invaluable tools for medical science? Lung Cancer 68:309-318

Graeser AC, Boesch-Saadatmandi C, Lippmann J et al (2011) Nrf2dependent gene expression is affected by the proatherogenic apoE4 genotype-studies in targeted gene replacement mice. J Mol Med 89:1027-1035

Graeser AC, Huebbe P, Storm N et al (2012) Apolipoprotein E genotype affects tissue metallothionein levels: studies in targeted gene replacement mice. Genes Nutr 7:247-255

Halliwell B (2003) Oxidative stress in cell culture: an underappreciated problem? FEBS Lett 540:3-6

Halliwell B, Gutteridge J (2007) Free radicals in biology and medicine. Oxford University Press, Oxford

Hixson JE, Vernier DT (1990) Restriction isotyping of human apolipoprotein $\mathrm{E}$ by gene amplification and cleavage with HhaI. J Lipid Res 31:545-548

Huebbe P, Jofre-Monseny L, Rimbach G (2009) Alpha-tocopherol transport in the lung is affected by the apoE genotype-studies in transgenic apoE3 and apoE4 mice. IUBMB Life 61:453-456

Huebbe P, Nebel A, Siegert S et al (2011) APOE epsilon4 is associated with higher vitamin D levels in targeted replacement mice and humans. FASEB J 25:3262-3270

Jeannesson E, Siest G, Zaiou M et al (2009) Genetic profiling of human cell lines used as in vitro model to study cardiovascular pathophysiology and pharmacotoxicology. Cell Biol Toxicol 25:561-571

Jofre-Monseny L, Pascual-Teresa S, Plonka E et al (2007) Differential effects of apolipoprotein E3 and E4 on markers of oxidative status in macrophages. Br J Nutr 97:864-871

Kornecook TJ, McKinney AP, Ferguson MT et al (2010) Isoformspecific effects of apolipoprotein $\mathrm{E}$ on cognitive performance in targeted-replacement mice overexpressing human APP. Genes Brain Behav 9:182-192

Lane DP, Crawford LV (1979) T antigen is bound to a host protein in SV40-transformed cells. Nature 278:261-263

Law GL, McGuinness MP, Linder CC et al (1997) Expression of apolipoprotein E mRNA in the epithelium and interstitium of the testis and the epididymis. J Androl 18:32-42

Long LH, Halliwell B (2012) The effects of oxaloacetate on hydrogen peroxide generation from ascorbate and epigallocatechin gallate in cell culture media: potential for altering cell metabolism. Biochem Biophys Res Commun 417:446-450

Long LH, Clement MV, Halliwell B (2000) Artifacts in cell culture: rapid generation of hydrogen peroxide on addition of (-)epigallocatechin, (-)-epigallocatechin gallate, $(+)$-catechin, and quercetin to commonly used cell culture media. Biochem Biophys Res Commun 273:50-53
Long LH, Hoi A, Halliwell B (2010) Instability of and generation of hydrogen peroxide by, phenolic compounds in cell culture media. Arch Biochem Biophys 501:162-169

Maezawa I, Nivison M, Montine KS et al (2006) Neurotoxicity from innate immune response is greatest with targeted replacement of $\mathrm{E} 4$ allele of apolipoprotein $\mathrm{E}$ gene and is mediated by microglial p38MAPK. FASEB J 20:797-799

Minihane AM, Jofre-Monseny L, Olano-Martin E et al (2007) ApoE genotype, cardiovascular risk and responsiveness to dietary fat manipulation. Proc Nutr Soc 66:183-197

Miyata M, Smith JD (1996) Apolipoprotein E allele-specific antioxidant activity and effects on cytotoxicity by oxidative insults and beta-amyloid peptides. Nat Genet 14:55-61

Mrkonjic M, Chappell E, Pethe VV et al (2009) Association of apolipoprotein E polymorphisms and dietary factors in colorectal cancer. Br J Cancer 100:1966-1974

Nardone RM (2008) Curbing rampant cross-contamination and misidentification of cell lines. Biotechniques 45:221-227

Olovnikov AM (1973) A theory of marginotomy: the incomplete copying of template margin in enzymic synthesis of polynucleotides and biological significance of the phenomenon. $\mathrm{J}$ Theor Biol 41:181-190

Ophir G, Amariglio N, Jacob-Hirsch J et al (2005) Apolipoprotein E4 enhances brain inflammation by modulation of the NF-kappaB signaling cascade. Neurobiol Dis 20:709-718

Oze H, Hirao M, Ebina K et al (2012) Impact of medium volume and oxygen concentration in the incubator on pericellular oxygen concentration and differentiation of murine chondrogenic cell culture. In Vitro Cell Dev Biol Anim 48:123-130

Qidwai T, Khan F (2011) Tumour necrosis factor gene polymorphism and disease prevalence. Scand J Immunol 74:522-547

Riddell DR, Zhou H, Atchison K et al (2008) Impact of apolipoprotein E (ApoE) polymorphism on brain ApoE levels. J Neurosci 28:11445-11453

Rihn BH, Berrahmoune S, Jouma M et al (2009) APOE genotyping: comparison of three methods. Clin Exp Med 9:61-65

Roy S, Khanna S, Bickerstaff AA et al (2003) Oxygen sensing by primary cardiac fibroblasts: a key role of p21(Waf1/Cip1/Sdi1). Circ Res 92:264-271

Schrader C, Rimbach G (2011) Determinants of paraoxonase 1 status: genes, drugs and nutrition. Curr Med Chem 18:5624-5643

Shampay J, Szostak JW, Blackburn EH (1984) DNA sequences of telomeres maintained in yeast. Nature 310:154-157

Sharp MG, Kantachuvesiri S, Mullins JJ (1997) Genotype and cardiovascular phenotype: lessons from genetically manipulated animals and diseased humans. Curr Opin Nephrol Hypertens 6:51-57

Shay JW, Wright WE (2007) Tissue culture as a hostile environment: identifying conditions for breast cancer progression studies. Cancer Cell 12:100-101

Shih DM, Lusis AJ (2009) The roles of PON1 and PON2 in cardiovascular disease and innate immunity. Curr Opin Lipidol 20:288-292

Singh PP, Singh M, Mastana SS (2006) APOE distribution in world populations with new data from India and the UK. Ann Hum Biol 33:279-308

Skrobot VN, Cukusic A, Ferenac KM et al (2007) Telomere dynamics and genome stability in the human pancreatic tumor cell line MIAPaCa-2. Cytogenet Genome Res 119:60-67

Smith JD (2002) Apolipoproteins and aging: emerging mechanisms. Ageing Res Rev 1:345-365

Smith JD, Melian A, Leff T et al (1988) Expression of the human apolipoprotein $\mathrm{E}$ gene is regulated by multiple positive and negative elements. J Biol Chem 263:8300-8308

Sullivan M, Galea P, Latif S (2006) What is the appropriate oxygen tension for in vitro culture? Mol Hum Reprod 12:653 
Venanzoni MC, Giunta S, Muraro GB et al (2003) Apolipoprotein E expression in localized prostate cancers. Int J Oncol 22:779-786

Vitek MP, Brown CM, Colton CA (2009) APOE genotype-specific differences in the innate immune response. Neurobiol Aging 30:1350-1360

Weisgraber KH, Rall SC Jr, Mahley RW (1981) Human E apoprotein heterogeneity. Cysteine-arginine interchanges in the amino acid sequence of the apo-E isoforms. J Biol Chem 256:9077-9083
Wu W, He Q, Li X et al (2011) Long-term cultured human neural stem cells undergo spontaneous transformation to tumor-initiating cells. Int J Biol Sci 7:892-901

Zannis VI, Cole FS, Jackson CL et al (1985) Distribution of apolipoprotein A-I, C-II, C-III, and E mRNA in fetal human tissues. Timedependent induction of apolipoprotein E mRNA by cultures of human monocyte-macrophages. Biochemistry 24:4450-4455

Zhang H, Wu LM, Wu J (2011) Cross-talk between apolipoprotein E and cytokines. Mediators Inflamm 2011:949072 